\title{
Analysis of Technical Efficiency in Mustard Production in Different Agro-Climatic Zones of Haryana and Punjab
}

\author{
Vishal Dagar ${ }^{1 *}$, Mahua Bhattacharjee ${ }^{2}$ and Param Jit ${ }^{3}$ \\ ${ }^{1}$ AER Centre, DSE, University of Delhi and Amity School of Economics, Noida, UP, India \\ ${ }^{2}$ Amity School of Economics, Amity University Uttar Pradesh, Noida, UP, India \\ ${ }^{3}$ Delhi School of Economics, University of Delhi, Delhi, India \\ "Corresponding author: dagarvishal99@gmail.com
}

\begin{abstract}
This paper help in analyzing Technical Efficiencies (TE), in different agricultural production stages for growing mustard, adopted by the farmers of Punjab \&Haryana in smallholding farming communities following the fast-track agricultural reform of the year 2014 with a view of highlighting key entry points for policy in the context of "Doubling of Farmers Income". Using a randomly selected sample of 350 smallholder mustard producers in the districts of south western Punjab and north western Haryana, a stochastic frontier production model was applied, using a linear Cobb-Douglas production function to determine the production elasticity coefficients of inputs, technical efficiency and the determinants of efficiency. The TE can be proved immensely helpful to avoid the situation of indebtedness, low yield and farmer's suicides in other Indian states. The study finds that mustard output responds positively to the increases in inorganic fertilizers, seed quantity, the use of labour and the area planted. The analysis for mustard growers depict 90 per cent of farmers in the study area, are technically efficient between 70 and 85 per cent, with an average of 77 per cent. The crucial factors of technical efficiency were the gender of head, size of family and frequency of extension services and visits, size of farm and the farming region. This paper represents a case study of south western Punjab and western Haryana to conclude the advanced middle stage farmers of both the state transforming the income generation from agricultural production by making possible use of efficient technology in production for High Yield Varieties (HYV) of mustard. JEL Codes: O21, O33, Q12, Q18
\end{abstract}

Keywords: Crop diversification, doubling farmers' income, farmer's suicides, high yield varieties, indebtedness, technical efficiency

The present study examines the level of technical efficiency across different agro-climatic zones in mustard farms of the northern Indian states of Punjab and Haryana. The studied regions are of the major mustard and other oil seed growing regions of India that is located in the north western extremity of the Indian peninsula north western Haryana (i.e. Jhajjar, Rewari, Hisar \& Sirsa) \& districts of South western Punjab (i.e. Sangrur, Mansa, Bathinda, Muktsar, Fazilka). The majority of small farmers grow mustard primarily for subsistence purposes. Per capita mustard production is slowly increasing with declining rate because of a significant decline in yield per hectare over time. In the 2010s, the smallholder mustard yield was around 1.2tonnes/ ha but after 2010 it dropped to about 1.0 tonnes/ha (Birthal, Khan, Negi \& Agarwal, 2014)

At present, the major challenge to the Ministry of Agriculture and Farmers Welfare (MOAFW) is to augmenting the income of small and medium farmers in all states. In India, we can expect such a relationship, given that agriculture contributes significantly to rural income for all farm households in general (with a total contribution of 41 per cent to total income) and for the bottom 20 per cent of farm households (nearly 50 per cent) in particular (Birthal, Khan, Negi \& Agarwal, 2014). 
The significance of the agricultural sector in rural area in the financial advancement of poor or developing nations has been perceived for a considerable length of time (Kuznets, 1966; Hayami \& Ruttan, 1985). Especially in developing agricultural economies i.e. India, where resources are meager and opportunities for developing and adopting better technologies are dwindling, (Ali and Chaudhry, 1990) efficiency measurement is very important because it is a factor for productivity growth.

The final results of the deterministic approach were highly sensitive in the selection of variables and to data errors (Bravo-Ureta, 2007). Aigner, Lovell, and Schmidt (1977) and Meeusen and van Den Broeck (1977) independently developed the stochastic frontier approach to define the limitations of the deterministic frontier approach.

Seyoum, Battese, and Fleming (1998) assume the technical efficiency and productivity of mustard producers in South Asian and compare production performance of the farmers within and outside an extension service programme for providing training and demonstration of new technology. Using Cobb-Douglas stochastic production frontiers, their study suggest that the landlords who participated in the training programme were highly technical efficient, with a very high level of significant mean for technical efficiency of 94 per cent, as compare to the 79 per cent for those outside the training project.
The maximum possible output, by using the available inputs and technology, can be represented by the production frontier. Fig. 1. The diagram shows a production frontier where the level of technical efficiency is optional or conditional on the level of inputs used (adapted from Battese, 1992). Output $(Y)$ is shown on they-axis and inputs $(X)$ on the horizontal axis. Technological change shows a shift of the production frontier, as new technologies enhance the output per unit of input to increase (Bravo-Ureta, 2007). Technical efficiency, on the other hand, explains the gap between expected (potential) and actual (observed) yield for a given level of technology and inputs.

\section{Methodology and Econometric Modeling}

\section{(a) Data collection and finalizing the sample size}

The cross-sectional data was collected through the household baseline study and it was conducted during November 2017 to April 2018 by the researchers at Agricultural Economics Research Centre, University of Delhi. The sampling frame was designed and drawn from farmer households in the six districts of Jhajjar, Hisar, Sirsa, Bathinda, Muktsar, \& Fazilka, which were selected on the basis of potential of the agro-climatic zones for sowing mustard and market access i.e. Jhajjar, Hisar, Ellenabad, Sirasa, Fatehabad are in the districts of

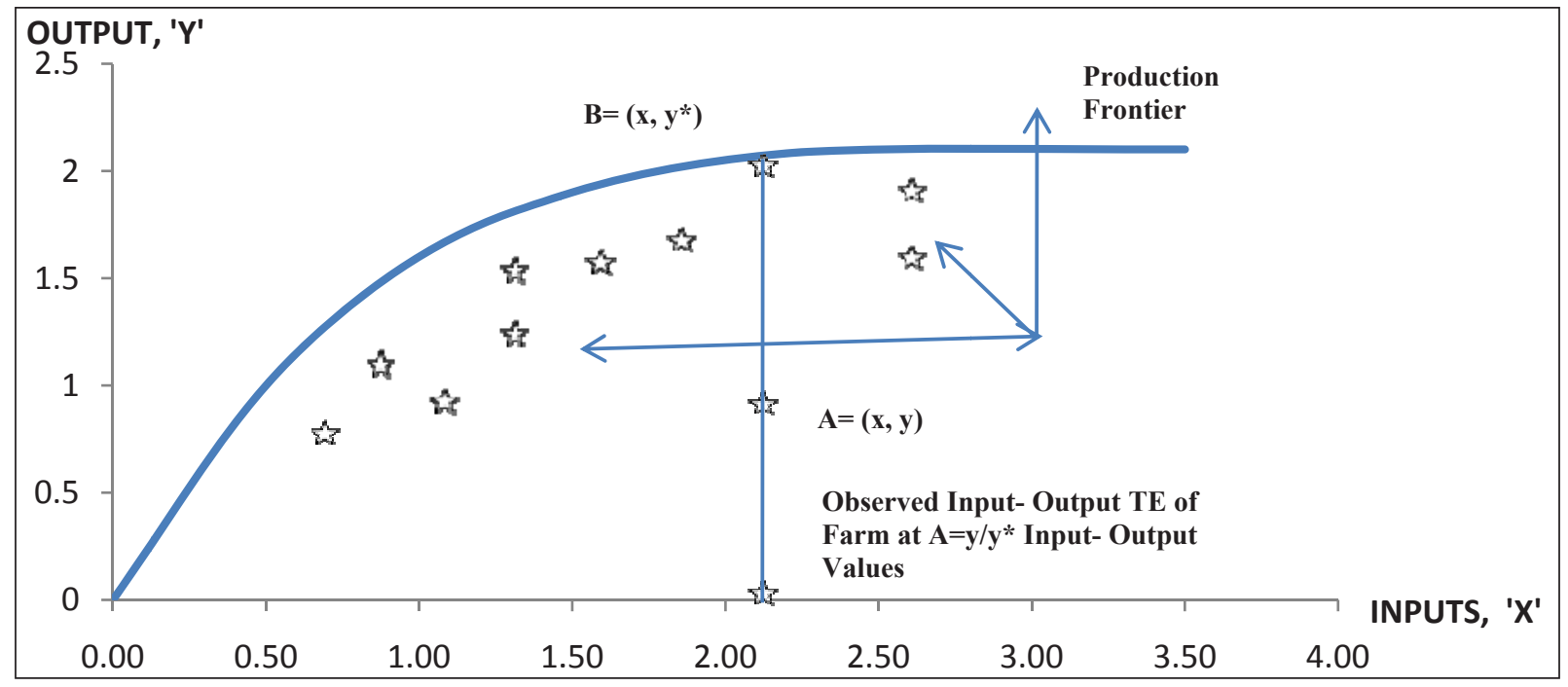

Fig. 1: Technical efficiency of farms in input- output space

Source: Battese (1992). 
Table 1: Agro-climatic, socio-economic cum geographic status

\begin{tabular}{ccccccc}
\hline State & District & Agro-climatic zone & $\begin{array}{c}\text { Rainfall } \\
(\mathbf{m m})\end{array}$ & $\begin{array}{c}\text { Mean } \\
\text { temperature }\left({ }^{\circ} \mathbf{C}\right)\end{array}$ & Main Crops & $\begin{array}{c}\text { Literacy Rate } \\
\text { (Percent) }\end{array}$ \\
\hline Haryana & Jhajjar & Eastern Zone & 532 & 34.4 & W,P,M1,M,J & 84.34 \\
Haryana & Hisar & Western Zone & 429 & 35.5 & W,P,M1,C,M,J & 75.00 \\
Haryana & Sirsa & North-Western Zone & 102 & 39.5 & W,P,M1,C,M,J & 68.00 \\
Punjab & Bathinda & South-Western Zone & 421 & 34.3 & W,P,M1,C,M,J & 68.28 \\
Punjab & Muktsar & South-Western Zone & 384 & 34.1 & W,P,M1,C,M,J & 69.00 \\
Punjab & Fazilka & Western-Zone & 307 & 34.5 & W,P,M1,C,M,J & 64.40 \\
\hline
\end{tabular}

*W-Wheat, P-Paddy, M1-Mustard, C-Cotton, M-Millet, J-Jowar; ** Data taken from government agency of the respective states.

Haryana and Killianwali, Bucho, Fazilka are in the districts of Punjab.

Four districts (Hisar, Sirsa, Bhatinda, Fazilka) fall under the high-potential agro-climatic zones in both the states, while Jhajjar and Muktsar are in marginally and low-potential agro-climatic zones. The data collection consist a primary household survey, using a précised and structured questionnaire. Random sampling was used to collect the data and also to select the villages and wards in all the six districts and the households to be personally interviewed from lists given by the resident agricultural development officers. The research was based on a sample of 350 small farm holders mustard producers randomly picked from the selected villages in different wards.

\section{(b) Econometric modeling}

This research paper uses the Cobb-Douglas production function form of the stochastic frontier production model with a normal log- normal log functional form following its merit for differentiating the density of technical efficiency for application in smallholder farming (see Binam, Tonye, Nyambi \& Akoa 2004; Mazvimavi, Ndlovu, An \& Murendo, 2012; Mochebele \& Winter-Nelson, 2000; Seyoum, Battese \& Fleming, 1998). The production and cost of cultivation related data in mustard production during April 2018 season by each of the 350 (around 60 mustard farmers per district) randomly selected households in all six districts of both the states.

The production function is specified as:

$$
\begin{array}{r}
\ln (\text { yield })=\beta_{0}+\beta_{1} \ln \left(X_{1}\right)+\beta_{2} \ln \left(X_{2}\right)+\beta_{3} \ln \left(X_{3}\right)+ \\
\beta_{4} \ln \left(X_{4}\right)+\beta_{5} \ln \left(X_{5}\right)+\varepsilon_{i}\left(V_{i}-U_{i}\right)
\end{array}
$$

Where,

yield $_{i}$ is the mustard output per hectare $(\mathrm{kg} / \mathrm{ha})$;

$\left(\beta_{0}-\beta_{5}\right)$ - are the parameters to be estimated;

$\ln \left(X_{1}\right)=$ Fertilizer - is the amount of fertilizer applied per hectare for mustard ( $\mathrm{kg} / \mathrm{ha})$;

$\ln (X)=$ Seed - is the mustard seed rate per hectare $(\mathrm{kg} / \mathrm{ha})$;

In $\left(X_{3}\right)=$ Irrigation - is the requirement of water required per $(\mathrm{kg} / \mathrm{ha})$ for the production of mustard (103.34 kilo liter water is required for mustard production in Haryana and Punjab);

In $\left(X_{4}\right)=$ Labour - constitutes family labour plus hired labour i.e. 8 hours per day per person (person-days);

$\ln \left(X_{5}\right)=$ Area - is the area put under sowing facility of mustard for the 2017 to 2018 (rabi crop production season) (ha);

$\varepsilon_{i}$ - is the error term, equal to $\left(V_{i}-U_{i}\right)$;

$V_{i}$ - is a two-sided random error component (exogenous variable) beyond the control of the farmer;

$U_{i}$ - is a one-sided inefficiency component.

The farm-specific technical efficiency $\left(\mathrm{TE}_{\mathrm{i}}\right)$ and existence of technical inefficiency of farms engaged in production has been a subject of considerable, relative and artificial in the concept of the production frontier of the $i^{\text {th }}$ farmer. The production frontier of the $i^{\text {th }}$ farmer was estimated using the expectation of $U_{i}$ conditional on the random variable $\varepsilon_{\mathrm{i}}$. Once all the inputs are taken into account to analyze the data, to measure productivity differences at different farm, should disappear except for random disturbances. 
The production frontier of the $i^{\text {th }}$ farmer follows that:

$$
T \varepsilon_{i}=\operatorname{Exp}\left(-u_{i}\right)
$$

So that, $0 \leq \mathrm{T} \varepsilon_{i} \leq 1$.

After obtaining the technical efficiency by including the endogenous as well as exogenous variables of mustard production, estimates for each small-holder mustard producer, using Equation (2) in primary data, a kernel density graph was produced in the STATA to find the trend line of the distribution of technical efficiency in the sample size of all the six districts of Haryana and Punjab.

Further, technical inefficiency determinants are specified with the following equation as:

$$
\ln \left(u_{i}\right)=\delta_{0}+\delta_{1}\left(c_{1}^{\prime}\right)+\ldots \ldots \delta_{n}\left(C_{1}^{\prime}\right)+\left(w_{i}\right)
$$

Where,

$\boldsymbol{u}_{i}$ - is technical inefficiency;

$\delta_{0} \ldots . . \delta_{n}$ - are the parameters to be estimated;

$\mathrm{C}_{1}{ }^{\prime}-\mathrm{C}_{i}{ }^{\prime}$ - is a vector of farmer and household socioeconomic characteristics;

$w_{i}$ - is a random error.

The stochastic production frontier function, earlier which was defined by Equation (1), and the technical inefficiency model for the sample size, defined here by Equation (3), was jointly estimated by the maximum likelihood (MLE) methods, by using Stata, version 12. A simple form of half-normal distribution curve of the inefficiency variance was used in the estimation by inputting the data of the 350 selected farmers of six districts of the states of Haryana and Punjab.

\section{RESULTS AND DISCUSSION}

Farmers with frequently availing the extension services were desired and expected to be more productive and efficient than non availing farmers, since they could obtain proper advice, information of government subsidies on currently available technologies in the market, better mustard germplasm, pest control and medicines or chemical related information on mustard production. Facilities to avail the institutional credit were seen as another important factor influencing the efficiency among small holder growers of mustard, which further enabling farmers to access the certified seed, trusted fertilizers and other important inputs i.e. irrigational facilities to improve their efficiency. Generally, families or households of farmers headed by male were assumed to be comparatively more production efficient in case of mustard.

Household size (no. of family members), the region (different districts of different states), expected price (future price of mustard in registered mandis) and the facility of treatment were assumed to have a very ambiguous impact on production hence it influence the technical efficiency for mustard production. The dependency of household size could also mean at a larger extent the head, which could again contribute to large poverty and lower living standard. In Table 2 a summary of different variables, their correlation values and their impact on technical efficiency defined that poorer farmers are likely to be more technically inefficient, as their socio-economic condition and status would not permit them to acquiring the necessary production inputs. While, age of the head is presumed to be negatively related with technical efficiency, following Goldman (2013), who finds that farmers with more age and farming experience tend to be more technically inefficient for agricultural production than younger ones.

\section{Data analysis \& summary of tests statistics}

The data was analyzed by using MS excel and STATA 12. The summary of tests statistics of mustard production data, geographical and the socio-economic features of the complete sample are presented in Table 3. The mean mustard production by the smallholder of land size producers is 944.13 $\mathrm{kg}$ (0.94 tonnes). On an average, small size of land holder mustard farmers used $83.45 \mathrm{~kg}$ of fertilizer (about one and half bags of $50 \mathrm{~kg}$ bags), used approximately $103.03 \mathrm{~kg}$ of water per $\mathrm{kg}$ production of mustard in a hectare, then the mustard farmers used $2.14 \mathrm{~kg}$ of seed, and allocated 1.42 ha of land to mustard. Each household had an average of about 2.43 ha of arable land and used at least three people per days (around 8 hours a day) of labour in the mustard fields.

In other terms of the geographical and socioeconomic features, in the small land holder producers of mustard in the sample size had a good availability to extension services: 72 per cent had obtained the various types of extension service visits, at an average of two to three visits 
Table 2: Summary of the variables, their correlation values and their expected impact on technical efficiency

\begin{tabular}{cccc}
\hline Variable & Description & Correlation value & Posited Sign (+/-) \\
\hline GendHHH & Gender of the house hold head & 0.651 & + \\
SizeHH & Size of the household & +1 to -1 & +- \\
WeednPestFre & Weeding and pest frequencies & 0.456 & + \\
CreditFac & Facility of credit & 0.324 & + \\
IrrigationFac & Facilities of irrigations & 0.834 & + \\
OthExtFreq & Other extension frequencies & 0.567 & + \\
Animalown & Owned animal and cattle & 0.259 & + \\
SqRooAgrHHH & Square root of age of house hold head & -0.236 & - \\
SqRooExp & Square root of number of years of experience of & 0.862 & + \\
& the house hold & & \\
FarmsizeLog & Log of the farm size & 0.753 & + \\
Region (dummy & Regiondum1 (Jhajjar) & +1 to -1 & $+1-$ \\
variable for & Regiondum2 (Hisar) & +1 to -1 & $+/-$ \\
districts) & Regiondum3 (Sirsa) & +1 to -1 & $+/-$ \\
& Regiondum4 (Bhatinda) & +1 to -1 & $+/-$ \\
& Regiondum5 (Mukatsar) & +1 to -1 & $+/-$ \\
EduSerDum & Regiondum6 (Fazilka) & +1 to -1 & $+/-$ \\
ExpPrice & Level of education of the head & 0.651 & + \\
Treatment & Expected price in market & 0.94 & + \\
& Dummy conservation agriculture & +1 to -1 & $+/-$ \\
\hline
\end{tabular}

per production season. Availability of institutional credit was less common among the farmers, at only 21 per cent of farmers in the total sample size.

The farmers were predominantly in male gender (84per cent), and the more than fifty per cent had attained at least education upto $5^{\text {th }}$ standard (93per cent). They were comparatively highly experienced, with more than 30 years of farming experience in fields on an average, and an average age of the farmers were found around 61.34 years. Agricultural animal ownership was also a relatively very common among the farmers, which is 75 per cent of farmers. The expected price of the crop of mustard has increased from the previous year and an average 94 per cent farmer of the total sample is expecting an increase in price of mustard in 2018. The sizes of the Household were relatively large (5-6 persons per household), which is a very commonly high concern given the small land tracts of total arable land they owned (2.43 ha). Weeding and pest frequencies averaged once per season. Just around a third (31per cent) of the farmers out of total sample practiced the conservation or traditional type agriculture pattern. This study gathered information of small land holder farmers of mustard from six districts of the states of Haryana and Punjab: 15 per cent from Jhajjar, 15 per cent from Hisar, 20 per cent from Sirsa, 20 per cent from Bhatinda, 15 per cent from Mukatsar and 15 per cent from Fazilka.

Table 4 depicts the maximum likelihood estimates (MLE) of the estimated deterministic stochastic frontier production function of the studied sample size and the major determinants of technical efficiency for the production of mustard. All the major as well as minor coefficients in the developed model for the productive factors (i.e. fertilizer, labour, irrigation, seed and sown area under mustard) are found positive. The coefficients of all the continuous variables are found significant at 1per cent, except for irrigation and labour, which are significant at 5 per cent. The coefficient for fertilizer of 0.27 indicates that mustard output is up to some extent elastic to changes in the using of the fertilizer. For example an increase of 1 per cent in fertilizer use should introduce an increase of 27 per cent for mustard output, and vice-versa. This is really not surprising at all, since the implication of fertilizer leads to an increase (a certain amount) 
Table 3: Mustard Production Data, Socio-Economic and Geographical Features of the House Hold

\begin{tabular}{|c|c|c|c|c|}
\hline Variables & Mean & $\begin{array}{c}\text { Standard Deviation } \\
\text { (SD) }\end{array}$ & Minimum & Maximum \\
\hline \multicolumn{5}{|c|}{ Continuous Variables $(n=350)$} \\
\hline Mustard Output (kg) & 944.13 & 1034.63 & 478 & 9861 \\
\hline Fertilizer Quantity Used (kg) & 83.45 & 93.58 & 50 & 17500 \\
\hline Irrigation (liter/kg) & 103.03 & 124.05 & 49234 & 1015683 \\
\hline Labour (men days 8 hrs per day) & 2.92 & 1.83 & 3 & 12 \\
\hline Seed Quantity Used (kg) & 2.14 & 1.56 & 2 & 15 \\
\hline Area Sown (ha) & 1.42 & 0.92 & 0.5 & 2.53 \\
\hline House Hold Size (units) & 6.34 & 5.03 & 4 & 32 \\
\hline $\begin{array}{l}\text { Frequency of weeding and pest } \\
\text { (no. of times in a season) }\end{array}$ & 1.02 & 0.42 & 1 & 3 \\
\hline Frequency of Extension Services (visit per season) & 2.58 & 5.16 & 2 & 4 \\
\hline Age of Head (years) & 61.34 & 21.34 & 32 & 84 \\
\hline Experience of farming (years) & 30.43 & 18.94 & 10 & 52 \\
\hline Farm size (ha) & 2.43 & 2.94 & 0.5 & 16 \\
\hline \multicolumn{5}{|c|}{ Categorical Variables $(n=350)$} \\
\hline Gender of HH Head ( $1=$ male) & 0.84 & 0.43 & 0 & 1 \\
\hline Education $\left(1=\right.$ at least $\left.5^{\text {th }}\right)$ & 0.93 & 0.39 & 0 & 1 \\
\hline Access of Extension Services $(1=$ yes $)$ & 0.72 & 0.26 & 0 & 1 \\
\hline Expected Price (1= Increase in previous year) & 0.94 & 0.81 & 0 & 1 \\
\hline Access of credit facilities $(1=$ yes $)$ & 0.21 & 0.42 & 0 & 1 \\
\hline Own Animal and Cattle $(1=$ yes $)$ & 0.75 & 0.72 & 0 & 1 \\
\hline regiondum1 (1= Jhajjar) & 0.15 & 0.62 & 0 & 1 \\
\hline regiondum2 $(1=$ Hisar $)$ & 0.15 & 0.71 & 0 & 1 \\
\hline regiondum3 ( $1=$ Sirsa) & 0.20 & 0.76 & 0 & 1 \\
\hline regiondum4 (1= Bhatinda) & 0.20 & 0.76 & 0 & 1 \\
\hline regiondum5 ( $1=$ Mukatsar) & 0.15 & 0.82 & 0 & 1 \\
\hline regiondum6 (1= Fazilka) & 0.15 & 0.83 & 0 & 1 \\
\hline Treatment ( $1=$ Conservation agriculture) & 0.31 & 0.43 & 0 & 1 \\
\hline
\end{tabular}

in production. This finding is consistent and can be compared with the Goldman (2013).

The highly positive coefficient for application of seed is some extent different and very surprising, since a high yield variety (HYV) seed use for mustard production in the studied area would tend to a lower rate and would be expected to be some extent negatively associated with production output of mustard. Goldman (2013) though, argued that the application rates of high yield variety seed would result in higher plant densities and reduced the full expansion of the plant, or an effect of overcrowding in baby plants of mustard, which would further have a negative impact on plant growth as well as a negative effect on output. One other explanation for the reduced output of mustard seeds could be that farmers have faced the problem of lack the institutional resources to purchase all the adequate, necessary and highly required inputs, and hence farmers tried to apply seed at a below-optimum rates than the normal rate. Should the farmers would be able to find a solution to increase the seed rate for lowering the seed inefficiency, that would certainly lead an increase in mustard output.

Labour and irrigation had a lower elasticity of 0.34 and 0.61 respectively, which would further implies that a 1 per cent increase in labour ( 8 hours per person-days), ceteris paribus, would tend to an increase 34per cent in mustard production. The significance of labour for mustard production is not surprising, since small land holder farmers are known to be resource-constrained or restricted to 
Table 4: Input elasticity and socio-economic determinants of inefficiency of mustard growers

\begin{tabular}{|c|c|c|c|c|c|}
\hline Variables & Description & Symbol & Coefficient & $\begin{array}{l}\text { Standard } \\
\text { Error }\end{array}$ & p-Value \\
\hline \multicolumn{6}{|l|}{ Productive factors } \\
\hline $\ln \left(X_{1}\right)$ & Log of Fertilizer & $\beta_{1} \ln \left(X_{1}\right)$ & 0.2657 & 0.0432 & $0.000^{*}$ \\
\hline $\ln \left(X_{2}\right)$ & Log of Seed & $\beta_{2} \ln \left(X_{2}\right)$ & 0.5934 & 0.0737 & $0.003^{*}$ \\
\hline $\ln \left(X_{3}\right)$ & Log of Irrigation & $\beta_{3} \ln \left(X_{3}\right)$ & 0.6112 & 0.0124 & $0.061^{* *}$ \\
\hline $\ln \left(X_{4}\right)$ & Log of Labour & $\beta_{4} \ln \left(X_{4}\right)$ & 0.3416 & 0.0178 & $0.032^{* *}$ \\
\hline $\ln \left(X_{5}\right)$ & Log of Area Sown for Mustard & $\beta_{5} \ln \left(X_{5}\right)$ & 0.1963 & 0.0634 & $0.001^{*}$ \\
\hline _Con & Constant & $\beta_{0}$ & 3.6781 & 1.5237 & $0.000^{*}$ \\
\hline \multicolumn{6}{|l|}{ Inefficiency effects } \\
\hline GendHHH & Gender of the House Hold Head & $\beta_{1}$ & -1.1524 & 0.3412 & $0.000^{*}$ \\
\hline SizeHH & Size of the HouseHold & $\beta_{2}$ & 0.0934 & 0.0417 & $0.063^{* * *}$ \\
\hline WeednPestFre & Weeding and Pest Frequencies & $\beta_{3}$ & -0.1884 & 0.2018 & 0.3502 \\
\hline CreditFac & Facility of Credit & $\beta_{4}$ & -0.8425 & 0.5438 & 0.3802 \\
\hline IrrigationFac & Facilities of Irrigations & $\beta_{5}$ & 0.0846 & 0.0423 & $0.053^{* * *}$ \\
\hline OthExtFreq & Other Extension Frequencies & $\beta_{6}$ & -0.0675 & 0.0334 & $0.039^{* *}$ \\
\hline Animalown & Owned Animal and cattle & $\beta_{7}$ & -0.0129 & 0.1276 & 0.617 \\
\hline SqRooAgrHHH & Square root of age of House Hold Head & $\beta_{8}$ & 0.0012 & 0.0247 & 0.435 \\
\hline SqRooExp & $\begin{array}{l}\text { Square root of no of years of experience } \\
\text { of the house hold }\end{array}$ & $\beta_{9}$ & -0.0032 & 0.0643 & 0.873 \\
\hline \multirow[t]{2}{*}{ FarmsizeLog } & Log of the farm size & $\beta_{10}$ & -0.4735 & 0.3184 & $0.091^{* * *}$ \\
\hline & regiondum1 (Jhajjar) & $\beta_{11}$ & -3.4516 & 0.5123 & $0.000^{*}$ \\
\hline \multirow{5}{*}{$\begin{array}{l}\text { Region (dummy } \\
\text { variable for districts) }\end{array}$} & regiondum2 (Hisar) & $\beta_{12}$ & -3.1387 & 0.5001 & $0.000^{*}$ \\
\hline & regiondum3 (Sirsa) & $\beta_{13}$ & 1.5463 & 0.0068 & $0.089^{* * *}$ \\
\hline & regiondum4 (Bhatinda) & $\beta_{14}$ & -2.4526 & 0.3943 & $0.000^{*}$ \\
\hline & regiondum5 (Mukatsar) & $\beta_{15}$ & -2.9428 & 0.4681 & $0.000^{*}$ \\
\hline & regiondum6 (Fazilka) & $\beta_{16}$ & 1.5673 & 0.0074 & $0.093^{* * *}$ \\
\hline EduSerDum & Level of Education of the Head & $\beta_{17}$ & -0.2341 & 0.6627 & 0.489 \\
\hline ExpPrice & Expected Price in Market & $\beta_{18}$ & -0.9467 & 0.8761 & 0.864 \\
\hline Treatment & $\begin{array}{c}\text { Dummy conservation agriculture } \\
\text { practice }\end{array}$ & $\beta_{19}$ & 0.4613 & 0.3276 & 0.193 \\
\hline _Con & Constant & $\beta_{0}$ & 0.8376 & 1.0067 & 0.298 \\
\hline \multicolumn{6}{|l|}{ Random error } \\
\hline _Con & Constant & $\omega_{i}$ & -1.7186 & 0.1273 & $0.000^{*}$ \\
\hline \multicolumn{6}{|l|}{ Other statistics } \\
\hline Likelihood ratio & & -386.8642 & & & \\
\hline Prob $>\chi^{2}$ & & $0.0000^{*}$ & & & \\
\hline No. of Obs. & & 350 & & & \\
\hline Wald $\chi^{2}(6)$ & & 284.62 & & & \\
\hline
\end{tabular}

${ }^{*} \rho<0.01 ;{ }^{* *} \rho<0.05 ;{ }^{* * *} \rho<0.10$.

some specific level of availability of input variables and mustard production is highly labour-intensive, which describes that the farmers are completely rely on heavily on manual labour. The farmers would therefore be highly conscious with maximizing their labour production and they would also tend to focus on increasing the technical efficiency in production of mustard. The estimated coefficient for irrigation would depict that an increase of 1 per cent in irrigational supply would tend to increase the 61 per cent of mustard output if other things will remain same in this case also.

The coefficient estimated for land used for sowing the mustard cultivation is 0.20 , which is showing 
that an increase of 1 per cent in the area cultivated would further introduce an increased change of 20 per cent in mustard output. This is again a very common trend, since the cultivated land is a very significant factor in mustard output. This result is also remaining same and consistent with the proof of those of Amaza and Olayemi (2002) and Coelli and Battese (1996).

The technical inefficiency parameters are shown in Table 4 which relate to the very much of farmspecific features and the farmers, geographic as well as socio-economic conditions. These parameters also include the gender of head of the farming family, number of family members (household size), frequencies of weeding and pest control practices, access to institutional credit, the expected future price of the crops, the frequencies of all other extension services, agricultural animal ownership, the age of the head, farming experience of the head, farm size of sown area, a dummy variable for all the six different districts of both the states (Haryana and Punjab), the level of education of the household head and the treatment applied for both type agricultural pattern (conservation or conventional agriculture).

The gender specific coefficient is estimated to be negative and found that is statistically significant at 1 per cent, which implies that male farmers are comparatively more efficient in mustard production. Taking into account that seeding, planting, irrigating, weeding or pest, harvesting, storing and other crop management and marketing operations are highly labour-intensive, these results are very common in nature. As the female farmers also participated in agricultural production of mustard but they have relatively less access to productive resources which would be proven very beneficial for mustard output. These results could also be very significant in terms of the explanation by the imbalance in productive resources are available and access by gender specifically. In the vast literature too, the allocation of agricultural resources to the poor women considered as a big hurdle and has a larger impact on production and productivity of a particular crop; hence the results obtained in this study could imply the comparatively lower technical efficiency of women-headed mustard growers that could be due to only lack of access and availability to productive resources for the production of mustard.
The coefficient of other important variable is household size is estimated to be positive and found statistically significant at 9per cent. This further implies that the smaller land holder farming households are more technically efficient, may be because, as stated earlier, larger the sizes of household exert more pressure on the highly limited resources or non-renewable sources of production, accessed by the small land holder farmers and it seem to be more exacerbate poverty. Poor farmers are more likely to be technically inefficient, as these farmers cannot afford to purchase the necessary productivity-enhancing inputs such as certified (HVY) seed and costly fertilizer, as well as the irrigational facilities. Moreover, bigger the size of household more is the expanses which lead to the increased dependency ratio in many cases in the studied sample. However, in contrast Wang, Cramer, and Wailes (1996), explain that household sizes more human resource can improve productivity and are positively related to technical efficiency in Chinese agriculture. The estimated coefficient for expected prices of the crops is found negative and also statistically highly significant factor influencing the production at a level of 10 per cent which depicts that farmers are having increased expect with government policies for the increase in prices of Minimum Support Price of mustard. The coefficient for the frequency of visits of other extension services is estimated to be negative and statistically significant at the 6 per cent level.

This is clearly indicating that more frequent visits for other extension services tend to increase the technical efficiency for the mustard growers, as an extension agent can provide advice on issues such as new existing technologies and very useful production-related information. This finding is very consistent and in the line with those of Seyoum, Battese \& Fleming (1998), Parikh, Ali \& Shah (1995) and Owens, Hoddinott \& Kensey (2003).

The size of the Farm is a significant determinant of the technical efficiency of small land holder mustard growers. The coefficient is estimated negative and statistically highly significant at 47 per cent, and implies that if a farmers with comparatively holding a large farm for arable land tend to be highly technical efficient. This could lead to fact that it is easy to cultivate the large farm with less labour and because of larger tracts that allow a mustard farmer 


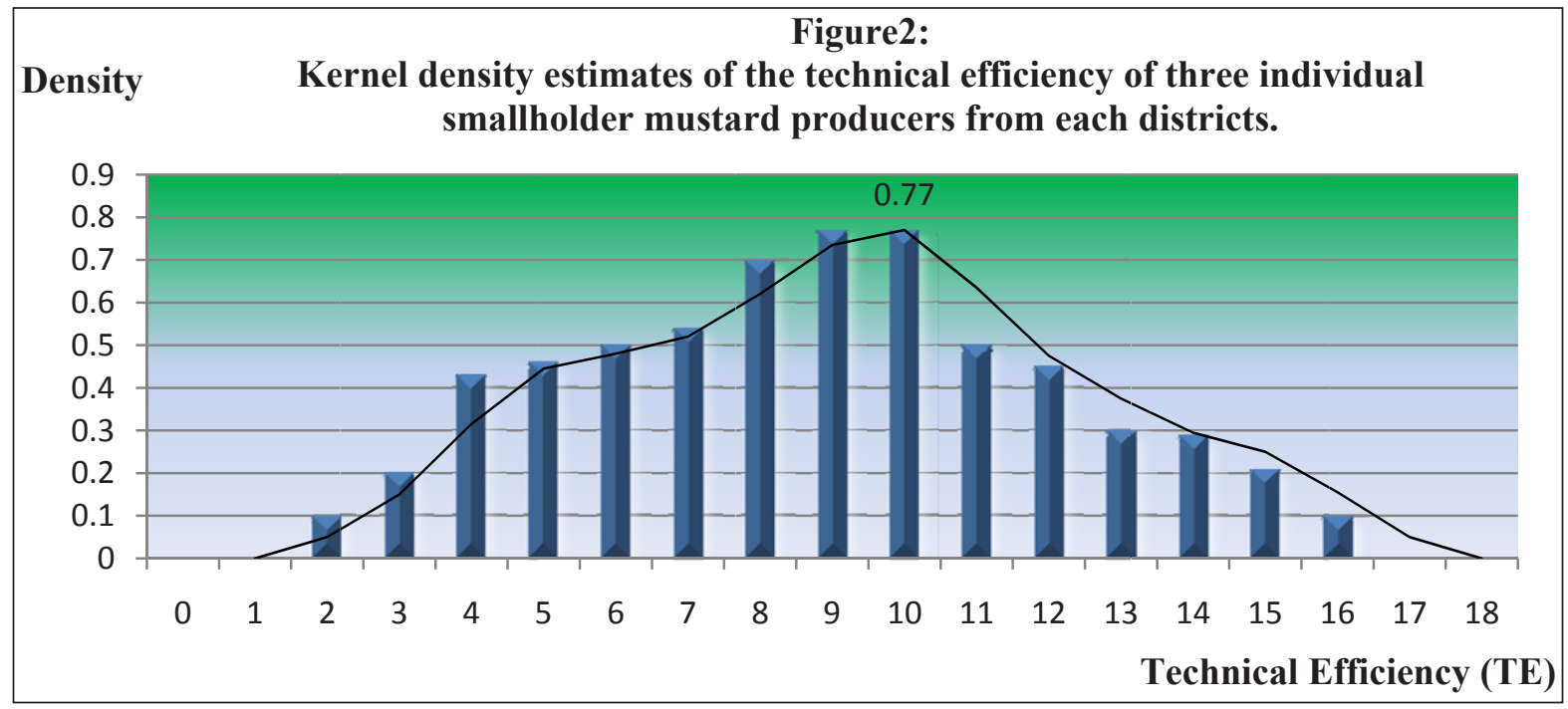

to diversify his different activities, for example by producing the cash crops (e.g. jowar and barsam) and keeping it very small for the livestock in addition to growing mustard. This should enable a farmer to generate an increase level of income, which would in turn enable him to increase his main crop productivity. This result is matched and consistent with that of Wadud and White (2000), who explained the technical inefficiency, is to decrease as size of the farm increases. In a different and opposite verdict given by Coelli and Battese (1996), and Parikh, Ali \& Shah (1995) who argue that the growers with small tracts are driven to allocate their scarce productive resources more technical efficiently. A dummy variable to capture the significance of region is also included in the model to explain fluctuations among the various districts.

Smallholder mustard producers in Jhajjar, Hisar, Bhatinda and Mukatsar tended to be comparatively more technically efficient (as the negative coefficients, significant at 1 per cent), but farmers who grow mustard those in Sirsa and Fazilka were relatively inefficient (positive coefficient, significant at 10 per cent). This is very common that since Jhajjar, Hisar, Bhatinda and Mukatsar are fall under very highpotential agro-climatic zones suitable for mustard with favorable temperatures and rainfall patterns (300-550 mm per year), while Sirsa and Fazilka are fall under low-potential agro-climatic zone with low rainfall and higher temperatures or unsuitable weather conditions for growing mustard. Farmers in low-potential zones of Sirsa and Fazilka tend to focus on more drought-resistant crops, such as cotton and gram. Other highly significant features of the deterministic stochastic frontier production function model are its capability to provide regular farm-specific estimates of technical efficiency in the production of mustard. Fig. 2 depicts that with a kernel density graph of three individual farmers from each district, farm-specific technical efficiency. The technical efficiency in production of mustard indices were forced to from an analysis of the stochastic production function for mustard growers.

The average mean level of technical efficiency used in the production of mustard for the sample of small land holder farmers is 0.77 (77 per cent), with a standard deviation of 0.6123 . This shows that, on the side of average, farmers could only go up to about 77 per cent of the maximum capacity to produce from a given set of mix input variables of production. These density distributions can scores between the ranges of 0.70 and 0.85 of the technical efficiency. About 85 per cent of the small land holder farmers have technical efficiency scores between 0.7 and 0.85 . These results can further suggest that mustard growers in India's small land holding sectors are restricted by a number of variables, such as very infrequent extension visits (two times per season on an average), smaller farm sizes of farmers (about less than 2 ha on average), comparatively larger number of members in household sizes (about 5-6 on an average), and lower agricultural production potential in most of the areas. The production potential for increasing the average technical efficiency among small land 
holder of mustard farmers in Haryana and Punjab is significant, at 38 per cent. This would further require more improving farmer-specific technical efficiency factor policies, such as the more frequent visits of extension services and proper land distribution and its utilization practices, more extensive irrigational facilities, given that the available sources in utilizing the farm sizes and those significantly influence technical efficiency of the production of mustard.

\section{CONCLUSION}

The present research study shows that fertilizer, irrigation, seed, and labour (both hired and family labour), as well as the area under mustard are the important variables attached with variations in mustard production. The impact of fertilizer on a specific production output is highly significant, also positive and the estimated coefficient is statistically proven significant at 1 per cent. The quantity of seed used for mustard production, the labour input used, and the size of the land used for cultivation of mustard output have positively impacted the mustard production, and also their coefficients are found statistically very significant at 1,5 and 10 per cent respectively. The model used in the study for analyzing the technical inefficiency impacts on the production frontier function for mustard growers includes gender of the head, numbers of the family members (household size), and frequency of other extension services, size of the sown farm and region (all six districts of Haryana and Punjab) as considered a significant determinants of technical efficiency for mustard producers. The male headship of households, the frequencies of visits of other extension services, and the regiondum 1 (Jhajjar), regiondum 2 (Hisar), regiondum 4 (Bathinda) and regiondum 5 (Mukatsar) are negatively considered to be attached with technical inefficiency, while household size and regiondum 3 (Sirsa) and regiondum 6 (Fazilka) had a very positive association with the technical efficiency.

The policies can be suggested out of these facts and findings are that the technical efficiency in small land holder for mustard output could be increased by 23 per cent on an average by using the better available resources (e.g. land, fertilizer, irrigation, seed and labour), in the given presently availability of technology. The state government of Haryana and Punjab could provide in enhancing the technical efficiency of the small land holder mustard growers, who contribute more than 60 per cent of total national mustard output, by defining a better controlled and more reliable support system from other extension services and empowering the gender i.e. women farmers. The women farmers could be empowered their participation level by (at least) defining that they are not marginalized (small in numbers) in availing institutional credit and other important productivity-enhancing input variables. Access to institutional credit, for instance, that would surely help them in ensuring their timely accessing the major input variables used for the production of mustard and thus they can promote their technical efficiency.

This research study, however, could only estimate the technical efficiency in small land holder for mustard production in Haryana and Punjab in India at a point in time during the November 2017 to April 2018. Given the major importance of staple oil seed mustard production to the food security in both rural and urban communities in the regional development, the small land holder farmers would further require cultivating as technically efficient as possible with the available input variables. As a conclusion from the analysis, which further contribute towards the current debate in India of finding ways of raising mustard productivity in the context of "doubling the farmers income" that has fallen or quite controversial due to the radical variations caused by the lack of technical efficient agricultural trend invasions since people are looking or shifting towards service sector since 2008. As a result, the estimates are indicating the some of the major factors of technical inefficiency in the present mustard production process in agriculturally developed states of Haryana and Punjab. The present monitoring system in India of measuring technical efficiency in mustard output is therefore necessary to estimate the changing agricultural pattern, in contexts of professional income generating source of the native residents of the different states and to inform policy actions should be taken by the government of the different state government.

\section{REFERENCES}

Aigner, D., Lovell, C.K. \& Schmidt, P. 1977. Formulation and estimation of stochastic frontier production function models. Journal of Econometrics, 6(1): 21-37. 
Ali, M. \& Chaudhry, M.A. 1990. Interregional farm efficiency in Pakistan's Punjab: a frontier Production function study. Journal of Agricultural Economics, 41(1): 62-74.

Amaza, P.S. \& Olayemi, J.K. 2002. Analysis of technical inefficiency in food crop production in Gombe State, Nigeria. Applied Economics Letters, 9(1): 51-54.

Anuradha, N. 2010. Technical efficiency of rice farms under irrigated conditions of central Gujarat (Doctoral dissertation, AAU).

Battese, G.E. 1992. Frontier production functions and technical efficiency: a survey of empirical applications in agricultural economics. Agricultural Economics, 7(3-4): 185-208.

Binam, J.N., Tonye, J., Nyambi, G. \& Akoa, M. 2004. Factors affecting the technical efficiency among smallholder farmers in the slash and burn agriculture zone of Cameroon. Food Policy, 29(5): 531-545.

Birthal, P.S., Khan, M.T., Negi, D.S. \& Agarwal, S. 2014. Impact of climate change on yields of major food crops in India: Implications for food security. Agricultural Economics Research Review, 27(2): 145-155.

Bravo-Ureta, B.E., Solís, D., López, V.H.M., Maripani, J.F., Thiam, A. \& Rivas, T. 2007. Technical efficiency in farming: a meta-regression analysis. Journal of Productivity Analysis, 27(1): 57-72.

Coelli, T.J. 1995. Recent developments in frontier modelling and efficiency measurement. Australian Journal of Agricultural Economics, 39(3): 219-245.

Coelli, T.J. \& Battese, G.E. 1996. Identification of factors which influence the technical inefficiency of Indian farmers. Australian Journal of Agricultural Economics, 40(2): 103-128.

Goldman, D. 2013. Technical efficiency of rice production in India: A study using stochastic frontier analysis to estimate technical efficiency and its determinants.

Larsen, M.N. 2002. Is oligopoly a condition of successful privatization? The case of cotton in Zimbabwe. Journal of Agrarian Change, 2(2): 185-205.

Hayami, Y. \& Ruttan, V. 1985. Agricultural Development: A Global Perspective.

Heshmati, A. \& Mulugeta, Y. 1996. Technical efficiency of the Ugandan matoke farms. Applied Economics Letters, 3(7): 491-494.

Kalirajan, K.P. 1991. The importance of efficient use in the adoption of technology: a micro panel data analysis. Journal of Productivity Analysis, 2(2): 113-126.

Kumbhakar, S.C., Ghosh, S. \& McGuckin, J.T. 1991. A generalized production frontier approach for estimating determinants of inefficiency in US dairy farms. Journal of Business E Economic Statistics, 9(3): 279-286.

Kuznets, S. 1966. Economic growth and structure. Heinemann Educational.

Llewelyn, R.V. \& Williams, J.R. 1996. Nonparametric analysis of technical, pure technical, and scale efficiencies for food crop production in East Java, Indonesia. Agricultural Economics, 15(2): 113-126.
Mano, R. 2006. Zimbabwe smallholder agriculture performance and recurrent food security crisis: Causes and consequences. CASS, UZ.

Mazvimavi, K., Ndlovu, P.V., An, H. \& Murendo, C. 2012. Productivity and efficiency analysis of maize under conservation agriculture in Zimbabwe. In Selected Paper for Presentation at the International Conference for Agricultural Economists Triennial Conference.

Meeusen, W. \& van Den Broeck, J. 1977. Efficiency estimation from Cobb-Douglas production functions with composed error. International Economic Review, pp. 435-444.

Mochebelele, M.T. \& Winter-Nelson, A. 2000. Migrant labour and farm technical efficiency in Lesotho. World development, 28(1): 143-153.

Msuya, E.E., Hisano, S. \& Nariv, T. 2008. Analysis of Technical Efficiency of Maize Farmers in Tanzania: The Globalization Era. In XII World Congress of Rural Sociology of the International Rural Sociology Association, Goyang, Korea.

Mugandani, R., Wuta, M., Makarau, A. \& Chipindu, B. 2012. Re-classification of agro-ecological regions of Zimbabwe in conformity with climate variability and change. African Crop Science Journal, 20(2): 361-369.

Owens, T., Hoddinott, J. \& Kinsey, B. 2003. The impact of agricultural extension on farm production in resettlement areas of Zimbabwe. Economic Development and Cultural Change, 51(2): 337-357.

Parikh, A., Ali, F. \& Shah, M.K. 1995. Measurement of economic efficiency in Pakistani agriculture. American Journal of Agricultural Economics, 77(3): 675-685.

Parikh, A. \& Shah, K. 1994. Measurement of technical efficiency in the North-West Frontier Province of Pakistan. Journal of Agricultural Economics, 45(1): 132-138.

Sen, A. 2017. Collective choice and social welfare: Expanded edition. Penguin UK.

Seyoum, E.T., Battese, G.E. \& Fleming, E.M. 1998. Technical efficiency and productivity of maize producers in eastern Ethiopia: a study of farmers within and outside the Sasakawa-Global 2000 project. Agricultural Economics, 19(3): 341-348.

Sherlund, S.M., Barrett, C.B. \& Adesina, A.A. 2002. Smallholder technical efficiency controlling for environmental production conditions. Journal of Development Economics, 69(1): 85-101.

Wadud, A. \& White, B. 2000. Farm household efficiency in Bangladesh: a comparison of stochastic frontier and DEA methods. Applied Economics, 32(13): 1665-1673.

Wang, J., Cramer, G.L. \& Wailes, E.J. 1996. Production efficiency of Chinese agriculture: evidence from rural household survey data. Agricultural Economics, 15(1): 17-28.

Weir, S. 1999. The effects of education on farmer productivity in rural Ethiopia. The Centre for the Study of African Economies Working Paper Series, 91.

Weir, S. \& Knight, J. 2000. Education externalities in rural Ethiopia: Evidence from average and stochastic frontier production functions. University of Oxford, Institute of Economics and Statistics, Centre for the Study of African Economies. 
